ISSN 1997-5902

\title{
Diversity of arbuscular mycorrhizal fungi in the rhizosphere of Coffea arabica in the Republic of Yemen
}

\author{
Abdul Hakim Noman Ali AL-AREQI ${ }^{1-2}$, Mohamed CHLIYEH ${ }^{1}$, Fadoua SGHIR ${ }^{1}$, Amina OUAZZANI \\ TOUHAMI ${ }^{1}$, Rachid BENKIRANE ${ }^{1}$ and Allal DOUIRA ${ }^{1}$ \\ 1 Laboratoire de Botanique et de Protection des Plantes, Université Ibn Tofaïl, Faculté des Sciences, B.P. \\ 133, Kénitra, Maroc (Morocco). \\ 2 Ministry of Agriculture and Irrigation, Yemen \\ Corresponding author email: douiraallal@hotmail.com
}

Original submitted in on 25th February 2013. Published online at www.m.elewa.org on $25^{\text {th }}$ April 2013.

http://dx.doi.org/10.4314/jab.v64i1.88478

\begin{abstract}
Objective: This study describes the status of mycorrhizal fungi in coffee (Coffea arabica) in the Yemeni ecosystems.

Methodology and results: Soil samples were extracted from the rhizosphere of the coffee tree groves in several regions of Yemen. The frequency and the level of colonization of the arbuscular mycorrhizal fungi (AMF) inside the root bark were measured by assigning an index of mycorrhization from 0 to 5 (Derkowska et al., 2008). The results showed that the AM fungal colonization structures were hyphae, coils and vesicles. The mycorrhizal frequency and intensity reached respectively 100 and $48 \%$ in the Taiz 2 site. The highest spore density was in the order of 100 spores $/ 100 \mathrm{~g}$ of soil and the genus Glomus was dominant. The tentative identification test of VAM (Vesicular Arbuscular Mycorrhizae) species, isolated from the rhizosphere of the coffee trees, revealed the presence of five fungal species:, Glomus proliferum, $G$. etunicatum, Acaulospora sporocarpia, Acaulospora sp.1, Archeospora sp. 1, Scutellospora nigra.

Conclusion and application of results: In all the studied sites the coffee roots were mycorrhized. These results demonstrate the existence of opportunities for the application of controlled mycorrhization in the coffee Seedlings nurseries.
\end{abstract}

Keywords: Yemen, Coffea arabica, rhizosphere, endomycorrhizae.

\section{INTRODUCTION}

Coffee is the world's most valuable agricultural export commodity. It is planted in more than 10 million hectares in over 50 countries (ICARD, 2002, in Mutandwa et al., 2009), and approximately 125 million people in Latin America, Africa, and Asia are dependent on coffee for their livelihoods (Osorio 2002 ; Lewin et al., 2004). Commercial coffee production relies on two species: Coffea arabica and C. canephora. Higher quality coffee is associated with $C$. arabica and this variety represents $73 \%$ of world production and almost all of the production in Latin America. $C$. arabica is the only tetraploid $(2 n=4 X=44)$ species in the genus Coffea, and is indigenous to the highlands of south-western Ethiopia, south-eastern Sudan and Yemen (Charrier and Berthaud, 1985). 
C. canephora (robusta coffee) makes coffee the second largest export commodity in the world after petroleum products, with an estimated annual retail sales value of US $\$ 70$ billion (Lewin et al., 2004). It is mainly grown in central and western equatorial Africa and comprises $80 \%$ of African production. Yemen is one of the most historic coffee-producing nations, having launched the trade of what has become one of the world's most important agricultural commodities (Anonymous, 2005).

Yemen's coffee farmers still practice traditional natural production methods, sometimes at very high altitudes of up to $2,500 \mathrm{~m}$ above sea level, which results in low yields. Coffee is one of Yemen's most important agricultural commodities. Most of Yemen's nearly 100,000 coffee farming families have small coffee plots with $1 / 4$ to 1 ha size and live in mountainous regions where about $45 \%$ of the population is considered to be below the poverty line (US \$2/day). Most Yemeni coffee is harvested from ancient types of Coffea arabica that have evolved locally for centuries and are practically grown nowhere else in the world (Anonymous, 2005). The cultivation of the arabica coffee began about five hundred years ago in Yemen and reached the southeast of Asia approximately in 1700 . At the beginning of the 18th Century, progenies of a single plant were taken from Indonesia to Europe and Later to America (Chevalier and Dragon, 1928). Originating from other introductions that took place from Yemen to Brazil, seeds of two different cultivars, Typica and Bourbon constitute the main genetic basis of all cultivated coffee planted in Brazil and other countries (Krag et al., 1939).

In spite of the semi-arid growing environment, a number of fungi and pests attack the coffee trees, affecting both quantity and the quality of the output. Most farmers have neither the resources nor the inclination to purchase and apply agrochemicals and rely on only a few traditional methods of control. According to researchers in the Ministry of Agriculture and Irrigation (MAl) of Yemen (Anonymous, 2005), crop losses are considerable but there are no clear estimations of how large they may be. Farmers certainly mention them but rarely as a top priority (Anonymous,
2005). According to the MAI of Yemen the key pests and diseases are Coffee leaf miner (Perileucoptera cofeella), Coffee Rust (Hemileia vastatrix), Coffee Berry Moth (Prophantis smaragdina) and Black Stem Borer (Apate monachus). The role of the arbuscular-mycorrhizal fungi (AMF) has been described as that of a fundamental link between plant and soil (O'Neil et al., 1991; Bethlenfalvay and Linderman, 1992; Miller and Jaslrow, 1994). Water deficiency is considered one of the most important abiotic factors limiting plant growth and yield. AMF can protect host plants from root pathogens and mitigate the effects of extreme variations in temperature, $\mathrm{pH}$ and water stress. Successful AMF inoculation at the beginning of acclimatization period has been demonstrated (Branzanti et al, 1992; Rai 2001; Estrada-Luna and Davies 2003). It is now accepted that the contribution of AM symbiosis to plant drought tolerance is the result of accumulative physical, nutritional, physiological and cellular effects. Mycorrhizal fungi, which are active in the rhizosphere, take part in the cycles and transfer of mineral elements in the soil and into the roots (George et al., 1992). Some minerals such as phosphorus, iron, zinc and copper are of very limited mobility in the soil and are only found in extremely low concentrations in soil solution. Their uptake and use by plants may be increased by the presence of symbiotic microflora, notably mycorrhizal fungi, which assist their nutrition, growth (Gianinazzi et al., 1982.; Smith and Read, 1997; Jeffries et al., 2003; Duponnois et al., 2005) and their tolerance to different types of biotic and abiotic stresses (Rosendahl and Rosendahl, 1991; Caravaca et al., 2003; Al-Karaki and McMichael, 2004; Selosse et al., 2004). AMF generally improve plant growth by enhancing the uptake of nutrients, especially Phosphate (Bolan et al., 1987, Marschner, 1995). In soils with strong P-fixing capacity, or where $\mathrm{P}$ is not adequately supplied, plant demand for this nutrient exceeds the rate at which it diffuses into the root zone, resulting in zones of $\mathrm{P}$ depletion surrounding roots. The AMF help overcome this problem by extending their external hyphae from root surfaces to areas of soil beyond the $\mathrm{P}$ depletion zone, there by exploring a 
greater volume of the soil than was accessible to the unaided root (Hayman, 1983). AM fungal hyphae are smaller in diameter than plant roots and therefore have a greater surface area per unit volume. This large surface area makes the fungi much more efficient than roots in the uptake of $P$. Moreover, the smaller diameter of AMF hyphae allows them to explore microspores in the soil that are not accessible to roots (Bolan, 1991). The presence of AM in coffee plants was first observed by Janse (1897), who found highly mycorrhizal coffee roots from Java Island. Since then, several

\section{MATERIALS AND METHODS}

Study sites: Yemen is situated in the northerly tropics and is mostly arid and semi-arid. Typically temperatures can exceed $40^{\circ} \mathrm{C}$ in many areas but decrease to $27^{\circ} \mathrm{C}$ in the highland and mountainous areas where most of the coffee is produced. Rainfall is highly erratic and occurs in two periods: from March through May and more heavily from July through September (Anonymous, 2005). The occupied area of the studies sites by coffee culture was 10795 ha taking $38 \%$ of the total occupied coffee area in Yemen and studies have verified the occurrence and importance of AM symbiosis in coffee, especially in highly weathered and low-fertility soils (Siqueira et al., 1998) such as those from many tropical regions where this crop is cultivated.

In this work, we have studied the mycorrhizal biodiversity of the coffee trees rhizosphere grown in different regions of Yemen. Indeed, little information is currently available on mycorrhizal fungi of coffee trees in Yemen and none of these works concerns the biodiversity of MA.

producing 4211 ha that had taken $38 \%$ of the coffee production in 2004 (Anonymous, 2005). The study sites have a semi-arid climate; the choice to study these sites was based on their coffee production. Sana'a, the capital of Yemen located in the middle of the republic, is the important coffee productive province followed by $\mathrm{lbb}$ in the second race, Dham'ar in the fifth one, also it was based on their elevation above the sea; Taiz has a lowest elevation above the sea (1355 m).

Table 1: Coordination and elevation of the five studied sites of Yemen.

\begin{tabular}{|c|c|c|c|c|}
\hline \multirow[t]{2}{*}{ Province } & \multirow[t]{2}{*}{ District } & \multirow{2}{*}{$\begin{array}{l}\text { Elevation above } \\
\text { sea } \quad(m)\end{array}$} & \multicolumn{2}{|c|}{ Coordination } \\
\hline & & & East & North \\
\hline Sana'a & Bani Matar (Bihash) & 2348 & 1679743 & 6395711 \\
\hline Dham'ar & $\begin{array}{l}\text { Almanar (Hammam } \\
\text { ali) }\end{array}$ & 1746 & 04111863 & 1621308 \\
\hline lbb & Dhi As-Sufal & 1726 & 0404655 & 1525050 \\
\hline Taiz 1 & $\begin{array}{l}\text { Mashrah and Hdan } \\
\text { (Aljanat) }\end{array}$ & 1530 & 0392162 & 1499245 \\
\hline Taiz 2 & Ataeziah (Al Hawban) & 1355 & 0398921 & 1504263 \\
\hline
\end{tabular}

The coffee groves of five different regions of Yemen (Figure 1): Sanaa, Taiz 1, Taiz 2, Dhamar and Ibb were surveyed during the month of September 2012 .The coordinates and altitude for the locations is shown in Table 1. 


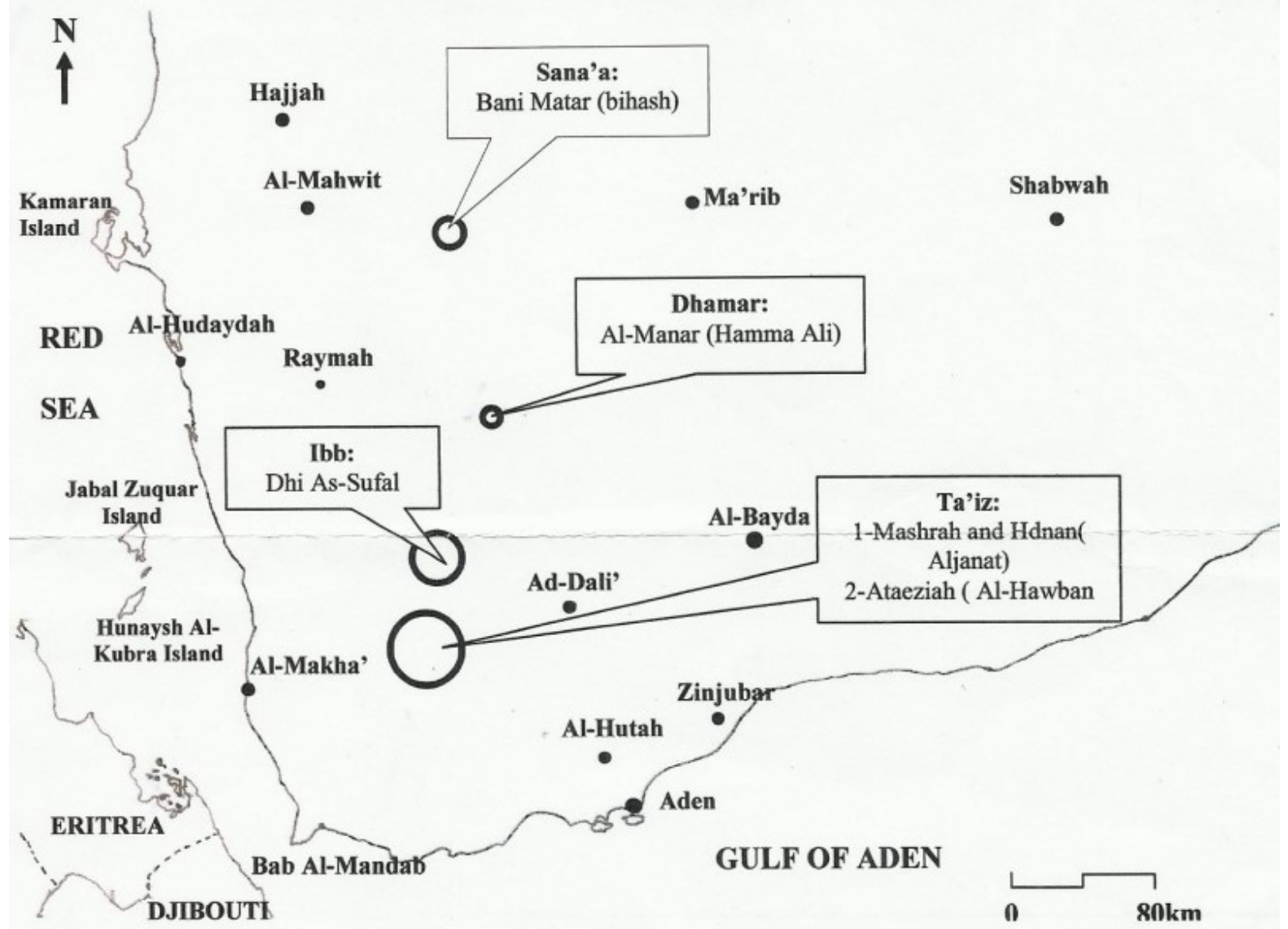

Figure 1: Geographical locality map of the sampling sites in Yemen

Soil and root sampling: Soil samples were taken from the rhizosphere of the coffee trees in several regions of Yemen. In each site, soil was sampled from five adult trees randomly selected. All samples were taken from a depth of $20 \mathrm{~cm}$, carried out at the foot of 5 trees / site (2 $\mathrm{kg} /$ tree) and a composite sample of soil was prepared at each site. Very fine roots were taken at the same time with the soil.

Physical and chemical soil analyzes: The rhizosphere soil was collected and its physicochemical characteristics were determined by conventional analyses performed in the soil analysis laboratory of 'Office Régional de Mise en Valeur Agricole du Gharb' (ORMVAG) in Kénitra (Morocco).

Spore extraction: VA mycorrhizal fungi produce different types of spores - zygospores, azygospores or chlamydospores. These spores are produced ectocarpically within the soil, root, hypogeous or in epigeous sporocarps (Irma et al., 1988). When the rootrhizosphere soil mixture contains a large amount organic material, the isolation of spores is preceded with density gradient centrifugation (Furlan et al., 1980).
Spores isolated from field-collected root-rhizosphere soil mixtures enable the revelation of spore abundance and species diversity of the arbuscular fungi sporulating in the field. Several techniques for the extraction of AM fungi spores from soil have been reviewed by Hayman (1983) and Schenck and Perez (1990). The wet sieving and decanting method as described by Gerdeman and Nicolson (1963), followed by sucrose density gradient centrifugation technique as described by Daniel and Skipper (1982) was used. Multiple layers of different densities can provide cleaner spores and are useful for separating different species.

The procedure was:

Step 1. $100 \mathrm{~g}$ of air-dried root-rhizosphere soil mixture was placed into a glass container with $1000 \mathrm{ml}$ of tap water. When the mixture contained rough soil, the glass with water and the mixture was kept in a refrigerator at $4^{\circ} \mathrm{C}$ for at least $12 \mathrm{~h}$.

Step 2 . The root-soil mixture was vigorously mixed with a glass rod for $30 \mathrm{sec}$.

Step 3. After 10-second pause to allow the heavier particles and organic material to settle, the remaining 
soil-root-hyphae-spore suspension was slowly poured through a set of two sieves. The top sieves had $0.5 \mathrm{~mm}$ pore diameters and the lower one was $0.045 \mathrm{~mm}$ diameter. Most spores retained on the $0.045 \mathrm{~mm}$ sieve. The top sieve isolates large sporocarps and spores associated with roots. The exercise was repeated three times for each sample.

Sucrose Centrifugation Technique: Spores and minimal amount of organic particles could be further purified by re-suspending sieving (filtered residues) in $50 \%$ sucrose solution followed by centrifugation. Sievings were transfered to $4 \mathrm{ml}$ centrifuge tubes with a fine stream of water from a wash bottle and centrifuged at $2000 \mathrm{rpm}$ for $5 \mathrm{~min}$. The supernatant was carefully removed to avoid disturbing the pellet. The soil particles were re-suspended in chilled $1.17 \mathrm{M}$ sucrose and centrifuged immediately at $2000 \mathrm{rpm}$, then at $3000 \mathrm{rpm}$ for $1 \mathrm{~min}$, applying the brake to stop the centrifuge. For the supernatant through the small mesh sieve, the spores were carefully rinsed held on the sieve with tap water and washed into a plastic Petri dish scribed with parallel lines spaced $0.5 \mathrm{~cm}$ apart. At the end, 0.05 grams of streptomycin were added to the AM Fungi solution to avoid any bacterial contamination. After extraction, endomycorrhizal spores were counted and identified basing on the morphological characters. The estimation of the number of spores in the soil was made by counting the spores in one $\mathrm{ml}$ of supernatant and extrapolating out of the total volume $(100 \mathrm{ml})$.

Quantification of AM Fungi Colonization in Roots: The AM fungi do not cause obvious morphological changes to the roots; however, they produce arbuscules and in many cases vesicles in roots. To observe AM fungal structures within the root it is necessary to clear cortical cells of cytoplasm and phenolic compounds which usually hide them and then to differentially stain the fungal tissue (Utobo, 2011). For non-pigmented roots, the clearing agent is generally $10 \% \mathrm{KOH}$ (potassium hydroxide) and some drops of hydrogen peroxide $\left(\mathrm{H}_{2} \mathrm{O}_{2}\right)$ (Phillips and Hayman , 1970). The KOH solution clears the host cytoplasm and nuclei and readily allows stain penetration (Irma Virant et al., 1988). $\mathrm{H}_{2} \mathrm{O}_{2}$ was used for decolourization of the host roots. The estimation of the coffee root colonization by mycorrhiza was through observation of the root system and the description of the mycorrhizal structures formed in the root. Finer roots were used ( $\leq 2 \mathrm{~mm}$ in diameter) (Hebert et al., 1999). Roots were cut to about $1 \mathrm{~cm}$ in length, washed with distilled water, dried with filter paper, and placed in a beaker containing $10 \% \mathrm{KOH}$ solution enough to cover roots. The beaker was transferred to a $90^{\circ} \mathrm{C}$ water bath and incubated for 45 minutes. The roots were transferred to a Petri dish, rinsed three times for 15 seconds with tap water at room temperature. They were placed in a beaker containing $100 \mathrm{ml}$ of distilled water and $0.05 \mathrm{~g}$ of cresyl blue, transferred to a $90^{\circ} \mathrm{C}$ water bath and incubated for 15 minutes.

Visualization of AM Fungi in Roots: The frequency and the intensity of arbuscules and vesicles of AMF inside the root bark were measured by assigning an index of mycorrhization from 0 to 5 (Derkowska et al., 2008). The method allowed determination of both the intensity and the qualitative presence or absence of colonization. Ten stained root fragments per root sample were mounted on a microscope slide; ten fields for each of ten $1.5 \mathrm{~cm}$ root pieces were examined and tallied for percent of root colonized under $40 x$ magnification with the optical microscope, for a total of 100 fields per plant. Percent root colonization was assessed based on three classifications: class 1: $0 \%$; no AM hyphal structures, nor vesicles, nor arbuscules were detected, class 2: $5 \%$; only 1 side of the root in the field is colonized and the hyphal structure does not cover the entire part of root section in the microscope field, class 3: $10 \%$; the entire field is covered with AM structures, the degree of colonization is highest at this level. All AM structures such as vesicles, arbuscules and hyphae were counted for presence of colonization. A root segment scores $100 \%$ colonization when all its ten fields respectively score $10 \%$. Mycorrhizal frequency, intensity and arbuscular content were calculated as below:

Mycorrhizal frequency (M.F \%) $=100 \times(\mathrm{N} 0-\mathrm{n} 0) / \mathrm{N}$ Where: $\mathrm{N}=$ number of observed fragments and $\mathrm{n} 0=$ number of non-mycorrhizal fragments.

Mycorrhizal intensity (M.I \%) $=(95 n 5+70 n 4+30$ $\mathrm{n} 3+5 \mathrm{n} 2+\mathrm{n} 1) / \mathrm{N}$

Where: $\mathrm{n}=$ number of fragments assigned with the index $0,1,2,3,4$ or 5 .

Arbuscular Content (A.C \%) $=(100 \mathrm{~mA} 3+50 \mathrm{~mA} 2+$ $10 \mathrm{~mA} 1)$ / 100

Where;

MA3, MA2, MA1 are the percentages (\%) respectively assigned to the notes $A 3, A 2, A 1$, with, MA3 $=(95 n 5$ $A 3+70 n 4 A 3+30 n 3 A 3+5 n 2 A 3+n 1 A 3) / N$.

The same for $A 1$ and $A 2$.

n5A3 represents the number of fragments marked 5 with $A 3 ; n 4 A 3$ marked the number of fragments 4 with A3; etc 
A0: no arbuscules, $\mathrm{A} 1$ : some arbuscules $10 \%, \mathrm{~A} 2$ : moderately abundant arbuscular $50 \%, A 3$ : very abundant arbuscular: $100 \%$.

Content of vesicles (V.C \% $)=(100 \mathrm{mV} 3+50 \mathrm{mV} 2+$ $10 \mathrm{mV} 1) / 100$

Where;

MV3, MV2, MV1 are the percentages (\%) respectively assigned notes $\mathrm{V} 3, \mathrm{~V} 2, \mathrm{~V} 1$, with $\mathrm{V} 3$;

$M V 3=(95 V 3 n 5+70 n 4 V 3+30 n 3 V 3+5 n 2 V 3+$ $\mathrm{n} 1 \mathrm{~V} 3) / \mathrm{N}$. The same for $\mathrm{V} 1$ and $\mathrm{V} 2 . \mathrm{n} 5 \mathrm{~V} 3$ represents

\section{RESULTS}

Physical-chemical soil analyses of coffee trees grown in different sites of Yemen (Table 4) have shown an alkaline $\mathrm{pH}$, higher than 7 . The highest percentage of organic matter content was in Taiz (between $3.07 \%$ in Taiz 1 and $3.51 \%$ in Taiz 2). The highest level of the mineral azotes was in Taiz 1 (201.76 ppm) and the the number of fragments marked 5 with $\mathrm{V} 3 ; \mathrm{n} 4 \mathrm{~V} 3$ marked the number of fragments 4 with $\mathrm{V} 3$;

V0: no vesicles; V1: some vesicles $10 \%$ V2: $50 \%$ moderately abundant vesicles; V3 abundant vesicles: $100 \%$.

Statistical Analysis: The statistical treatment of results focused on the analysis of variance with a single classification criterion (ANOVA1).

lowest was in Dhmar (122 ppm). Different levels of the phosphorus, varying from 8 to $86 \mathrm{ppm}$. The available potassium content reached $951 \mathrm{ppm}$ in the soil of Dhmar and $446 \mathrm{ppm}$ in the soil of Taiz1. The rate of carbon fluctuates between $0.91 \%$ (at Sana'a) and 2.04 $\%$ (at Taiz 2).

Table 4: Physical and chemical properties of soil samples at five coffee growing sites in Yemen sampled for mycorrhizae studies.

\begin{tabular}{llllllllll}
\hline Locality & $\mathbf{p H}$ & $\begin{array}{l}\text { Sodium } \\
(\mathbf{m e q 1 0 0})\end{array}$ & $\begin{array}{l}\text { Organic } \\
\text { matter } \\
(\%)\end{array}$ & $\begin{array}{l}\text { Organic } \\
\text { carbon } \\
(\%)\end{array}$ & $\begin{array}{l}\text { nitric } \\
(\mathbf{p p m})\end{array}$ & $\begin{array}{l}\text { ammoniacal } \\
\text { Azote }(\mathbf{p p m})\end{array}$ & $\begin{array}{l}\text { mineral } \\
\text { Azote } \\
(\mathbf{p p m})\end{array}$ & $\begin{array}{l}\text { Phosphorus } \\
\text { (ppm) }\end{array}$ & $\begin{array}{l}\text { Potassium } \\
\text { (ppm) }\end{array}$ \\
\hline Sana'a & 7.82 & 0.22 & 1.57 & 0.91 & 163.68 & 19.44 & 183.12 & 8 & 787 \\
Taiz 1 & 7.89 & 0.2 & 3.07 & 1.78 & 179.80 & 21.96 & 201.76 & 13 & 446 \\
Taiz 2 & 8.06 & 0.31 & 3.52 & 2.04 & 173.60 & 12.60 & 186.20 & 86 & 881 \\
Dhmar & 8.51 & 0.7 & 2.33 & 1.36 & 109.12 & 13.68 & 122.80 & 24 & 916 \\
lbb & 7.79 & 0.2 & 1.92 & 1.11 & 148.80 & 5.40 & 154.20 & 11 & 951 \\
\hline
\end{tabular}

The Microscopic observations have shown that the roots of the cultivated coffee were colonized by endomycorrhizal fungus. Different endomycorrhizal structures have been observed at each site (Fig. 2): arbuscules (Fig. $2 \mathrm{x}$ ), which seemed to ramify along the cortex of roots and vesicles often with an oval shape that were present between cells of the cortex.
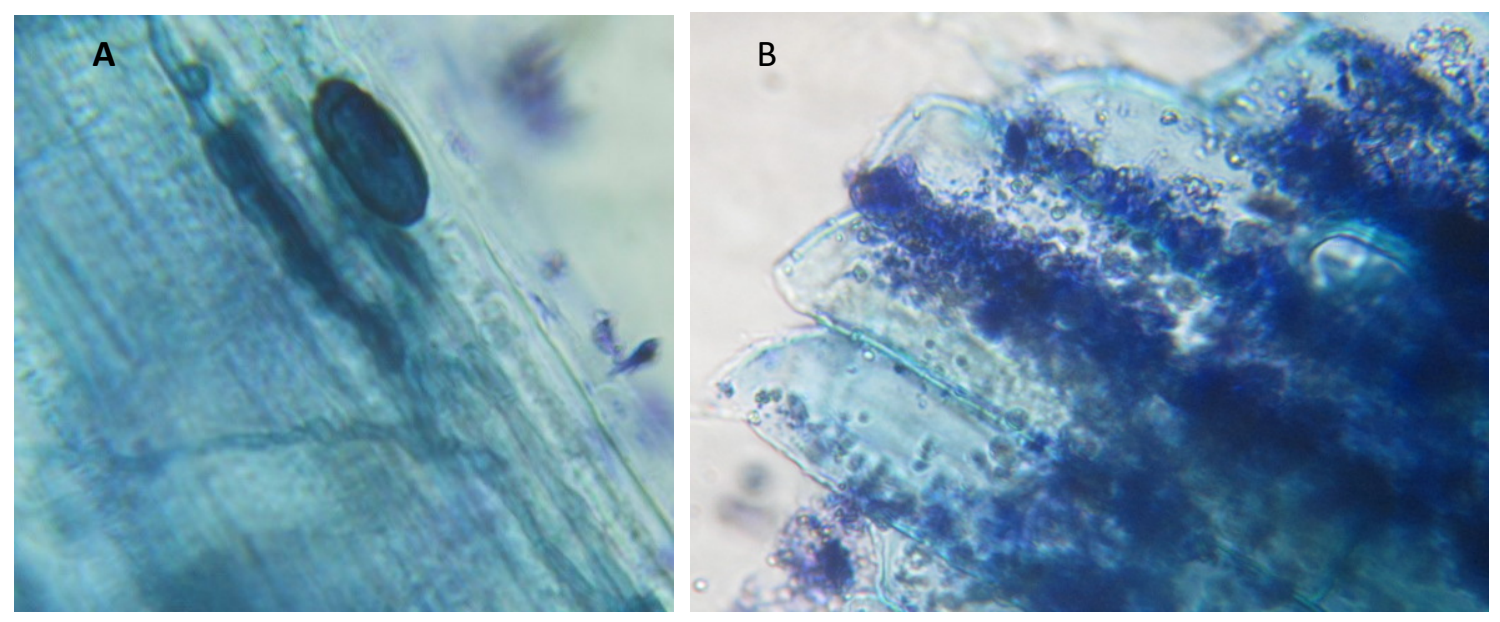


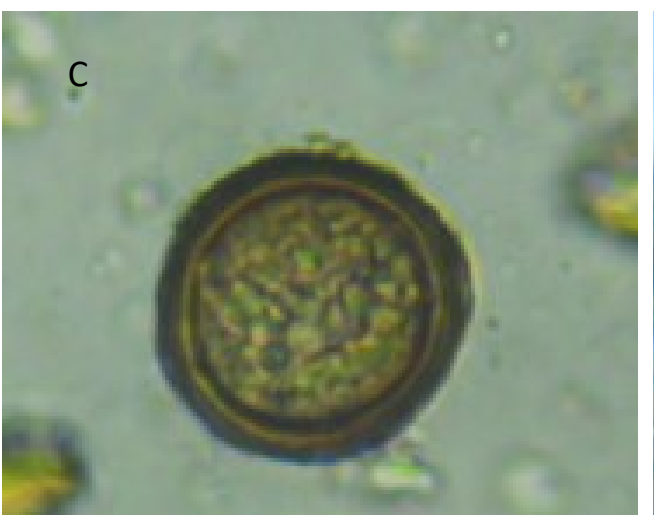

$17,82 \mu \mathrm{m}$

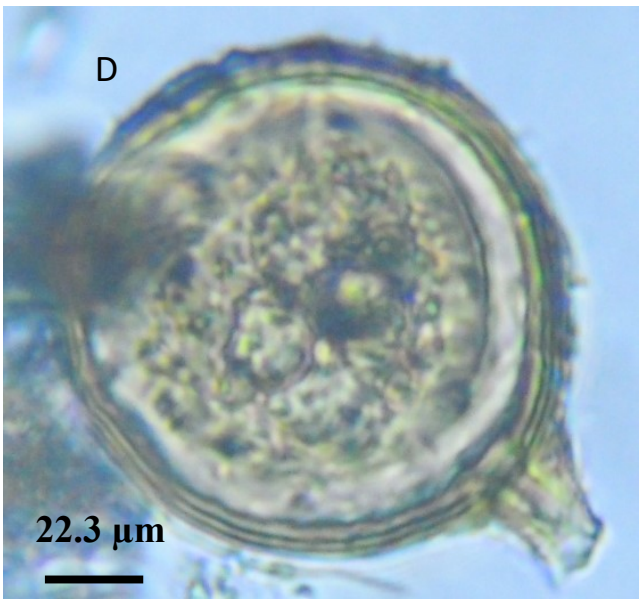

Fig. 2: AM fungi spores and structures inside the roots of the coffee seedling; $(A)$ : vesicule and hyphae of the AM fungi; (B): Arbuscules; (C): Glomus etunicatum; (D): Glomus sp.

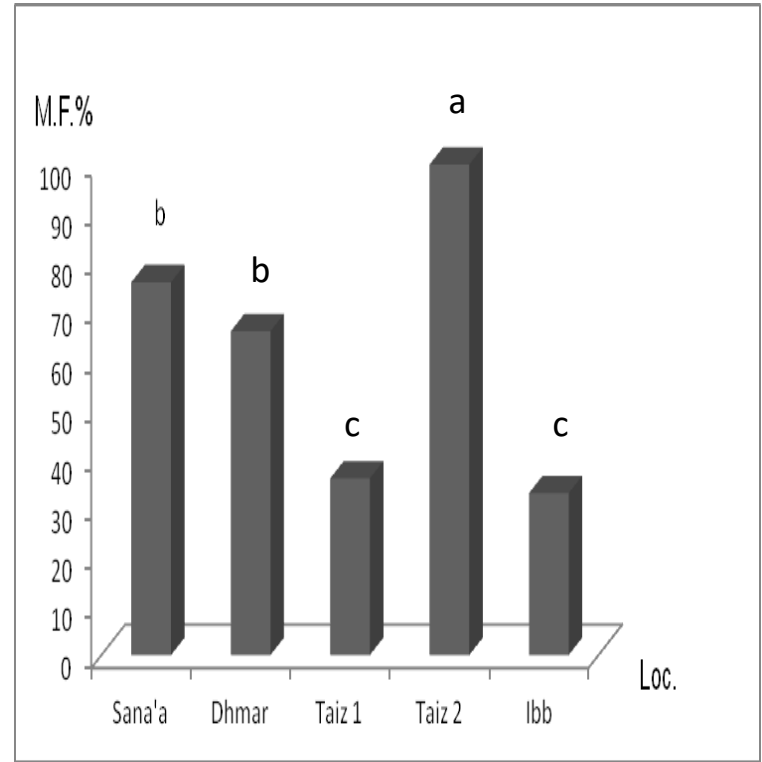

Figure 3: Mycorrhizal frequency (M F :\%) of coffee roots.

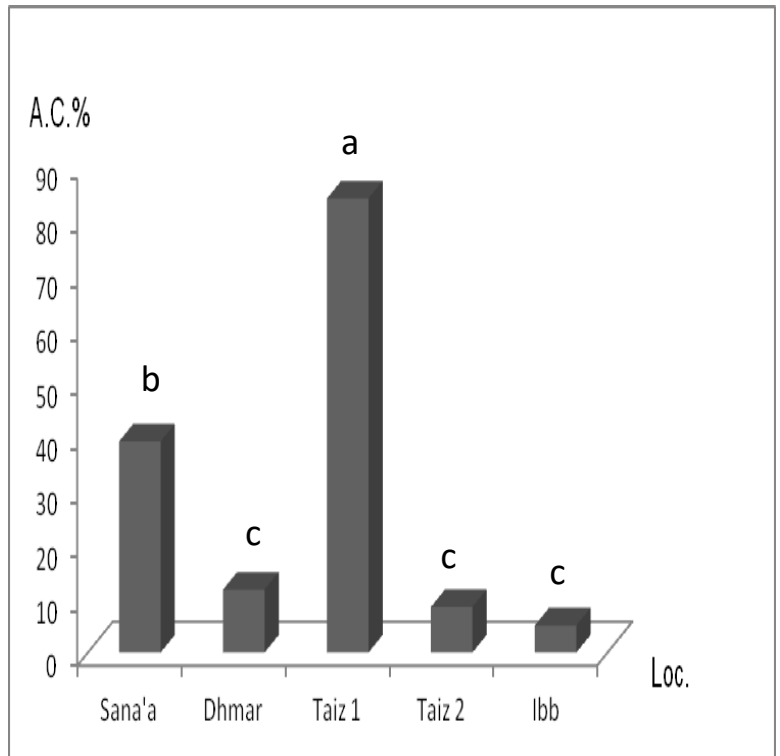

Figure 4: Arbuscular content (A.C \%) of coffee ronts in the studv sites. 


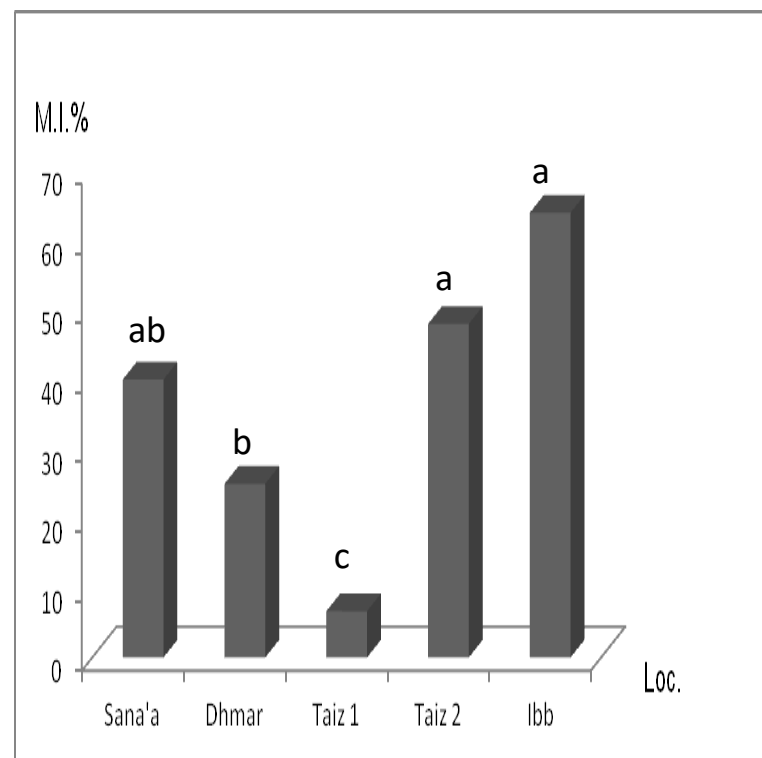

Figure 5: Mycorrhizal intensity (M.I \%) of coffee roots in the studv sites.

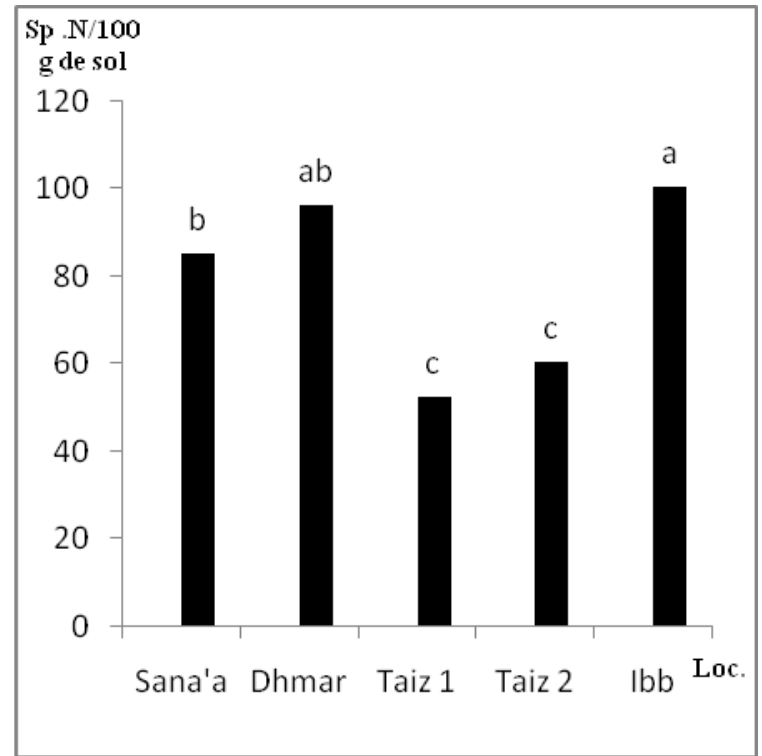

Figure 7: Spores density (spores number $/ 100 \mathrm{~g}$ of soil) of the AM fungi in the rhizosphere of the coffee in the study sites.

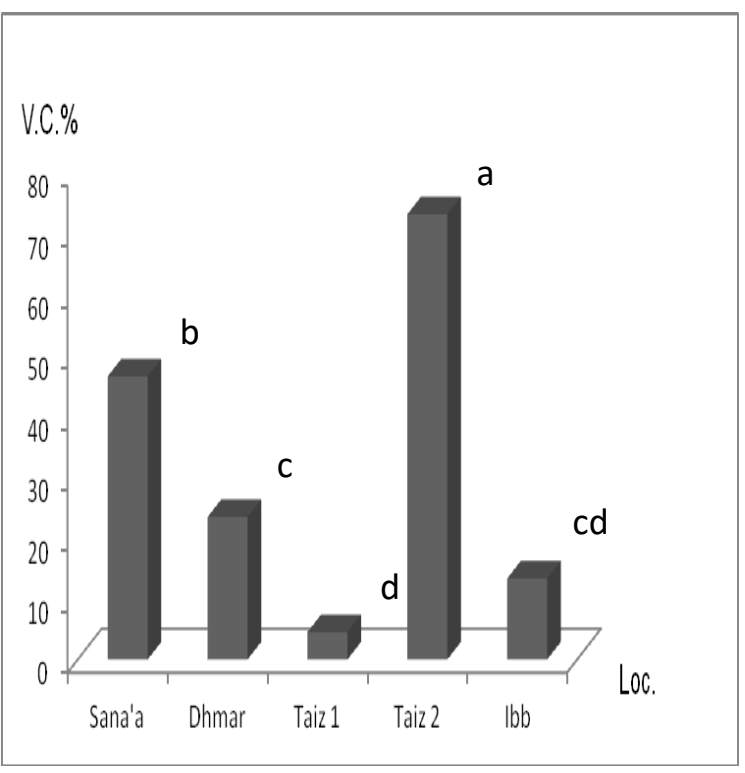

Figure 6: Vesicular content (V.C \%) of coffee roots in the studv sites.

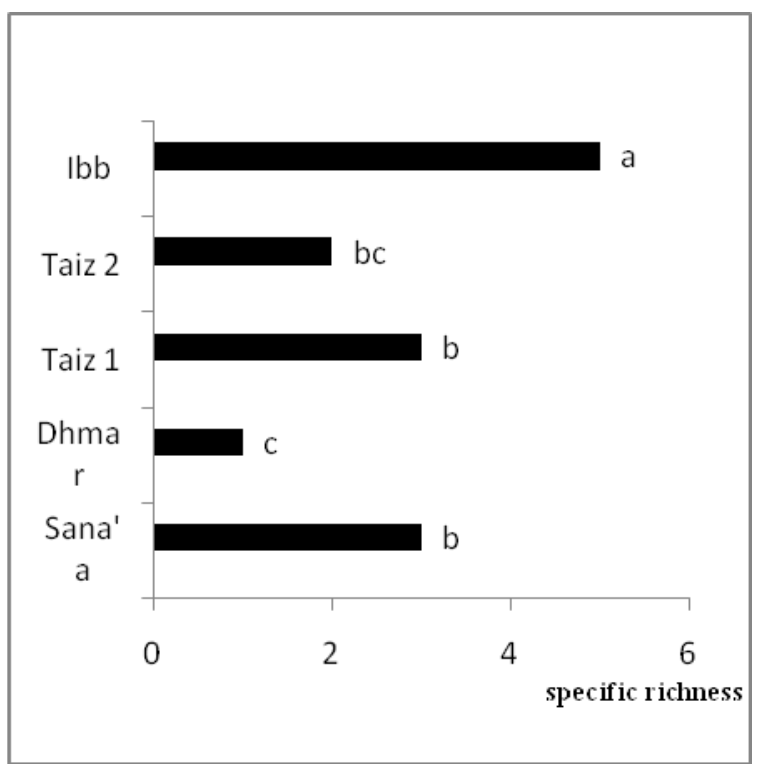

Figure 8: The specific richness of the AM fungal species detected in the rhizosphere of coffee in the study sites. 


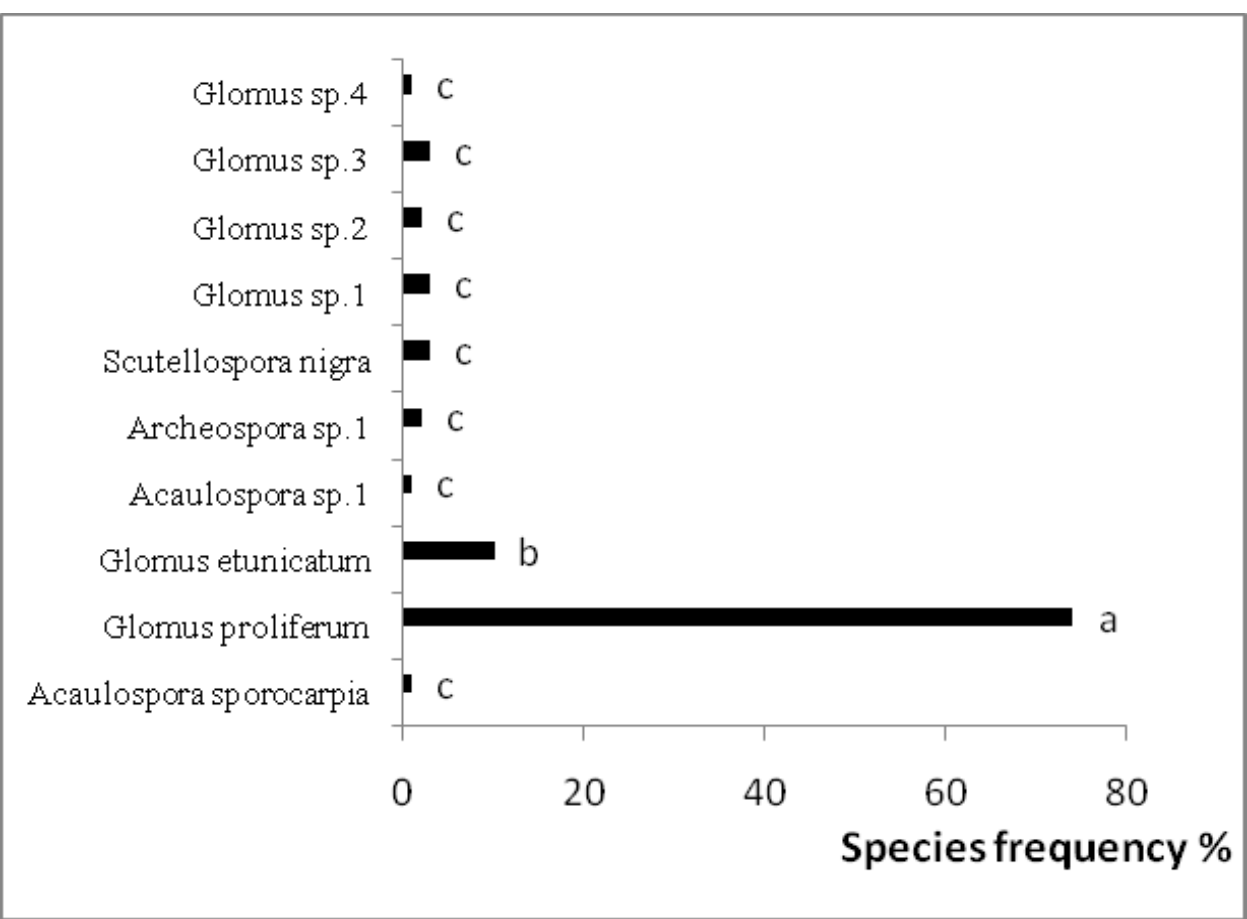

Figure 9: The species frequency of the AMF in five coffee growing sites in Yemen

Statistical analysis showed that the Mycorrhizal frequency of coffee roots was different in the studied sites; Taiz 2 showed the highest frequency (100\%) and lbb lowest (33\%) (Fig. 3). The arbuscular content of coffee roots was different in the studied sites; the highest content was in Taiz 1 (84\%) and lowest in lbb $(7 \%)$ (Fig. 4). The highest Mycorrhizal intensity of coffee roots was in Ibb (64\%); no statistical difference was observed between the mycorrhizal intensity at lbb, Taiz 2 and Sana'a, while it was lowest in Taiz 1 (6.66 $\%$ ) (Fig. 5). The highest vesicular content of coffee roots was in Taiz 2 (73\%) and the lowest in Taiz 1 $(4.5 \%)$ (Fig. 6). Spore density of AM fungi in coffee

\section{DISCUSSION AND CONCLUSION}

In all the studied sites the coffee roots were mycorrhized. Coffee has often been considered to have high mycorrhizal dependency, especially during the seedling formation stage (Sieverding and Toro, 1986; Siqueira et al., 1993; Habte and Bittenbender, 1999), the contents of arbuscules and vesicles were highly variable. The highest content of arbuscular was registered in the site of Taiz 1 and the vesicular content at the sites of Taiz 2. The variability of the mycorrhizal frequency from one site to another can be explained by the differences in the physico-chemical properties of substrates; the variation in soil $\mathrm{pH}$, temperature, and effluent pollution seems to be the decisive factors in rhizosphere varied from one site to the other; Taiz 1 had the lowest spore number (52 spores / $100 \mathrm{~g}$ of soil) and Ibb had the highest (100 spores/100 g of soil) (Fig. 7). The richest site with the arbuscular mycorrhizal fungi was lbb with five different species, Taiz 1 and Sana'a had the same specific richness with two different species and Dhmar was the poorest site with only one species (Fig. 8). Glomus proliferum (74\%) was the dominant morphospecies at regional level (Fig.9), followed by Glomus etunicatum (10\%); the lowest species frequency was in Acaulospora sporocarpia, Acaulospora sp.1 and Glomus sp. 4 with 1\% (Fig.9).

tropical soils influencing distribution of VAM fungi. (Mahesh and Selvaraj, 2008). Basing on the morphological characters of spores, four groups of AMF were identified. These results were identical to those of Tadesse Chanie (2006) in South Western Ethiopia. The number of mycorrhizal species may increase after using the bait technique (Sghir et al., 2013). Basing in composition, species richness, diversity and dominance of the AMF morphospecies spores Lopes et al. (1983) recorded 27 coffee production systems from Brazil; 10 AMF morphospecies was isolated in five coffee production systems of Coffee arabica in Yemen. The fluctuation in the number of MVA spores observed 
could be attributed to the process of spore formation, their germination and degradation (Smith, 1980), the sampling season (Gemma et al., 1999), soil and climatic variations (Koske, 1987; Johnson et al., 1991) and soil microorganisms (Dalpe, 1989). We found the spores of genera Glomus to be dominant, as has been reported elsewhere from Latin America (Lopes et al. 1983; Cruz 1989) and southwestern Ethiopia (Muleta et al., 2008; Jefwa et al., 2009), dry Afromontane forests of Ethiopia (Tesfaye et al., 2004), the tropical rain forest of Xishuangbanna, China (Zhao et al., 2001), tropical rain forest in Mexico (Guadarrama and AlvarezSanchez, 1999), and the arid and semi arid lands of North Jordan (Mohammad et al., 2003). Different authors have associated the high incidence of Glomus spores with their capacity to produce more spores in a shorter time than other genera such as Gigaspora and Scutellospora (Bever et al., 1996). According to their relative abundance and frequency of occurrence, Glomus etunicatum was the dominant morphospecies at regional level. In addition to the effectiveness of Glomus in improving coffee seedling growth in glasshouses (Fernandez-Martin et al., 2005), it has been noted that this species can increase $P$ concentration in Gliricidia sepium (Twum-Ampofo, 2008). According to our results, Glomus species frequency in the coffee study sites was $93 \%$. Mangan and Alder (2000) reported that Glomus species were also the most frequently encountered fungi in the fecal samples collected from terrestrial and arboreal small mammals in a Panamian cloud forest with $87 \%$ frequency of occurrence in the samples. Frioni et al., (1999) had noted that the acidic soil pH might favor this genus (Glomus), which is not in agreement with our results, where physico-chemical soil analyses showed an alkaline $\mathrm{pH}$. The highest spore counts were in $\mathrm{lbb}$, Dhamar and in Sana'a. This might be due to the cumulative effect of low level of $P$. These features make this fungus a promising morphospecies to be

\section{REFERENCES}

Anonymous, 2005. Moving Yemen Coffee Forward. United states Agency for International Development Inc., 88 pp.

Alexander I. J., 1989. Mycorrhizas in tropical forests. In: Mineral Nutrients in Tropical Forest and Savanna Ecosystems. J Proctor (ed.) Blackwell Scientific Publications, pp.169-188.

Al Karaki G., McMichael B. and Zak J., 2004. Field response of wheat to arbuscular mycorrhizal considered in future studies, since most of the soils in the study area are low in available P (Geissert and Ibanez, 2008). At Taiz 1 the level of $P$ was lower and the spore density was lowest, possibly due to the high level of organic matter. Several studies have reported suppression of mycorrhizae in the presence of high nutrient contents (Sieverding, 1991).

The pattern of percent root infection was also found to vary between the study sites, the highest mycorrhizal intensity was in Ibb and lowest in Taiz 1, which may reflect spore density in each site. Nevertheless, the exception was that at Taiz 2 mycorrhizal intensity had no significant difference to that of lbb knowing that Taiz 2 had fewer spores than $\mathrm{lbb}$. The variations in species with regard to the degree of colonization and presence/absence of AMF in the same or different sites seems to indicate that environmental factors linked to the host influence the presence and mycorrhizal colonization level (Alexander, 1989). Such variation of root colonization at genus and family levels have been reported (St. John, 1980).

This study of the natural diversity of arbuscular mycorrhizal fungi in the rhizosphere of the coffee trees in Yemen is a starting point to develop inoculants suitable for use in the nursery to get coffee plants that may be more robust and resistant against pathogens, drought and salinity stress after transplanting. The knowledge about the functional diversity of Arbuscular Mycorrhizal Fungi (AMF) is an important ecological issue that deserves greater research efforts especially when trying to use them in biotechnological approaches in horticulture, forestry and ecological restoration. Diversity of AMF is almost unexplored in Yemen, and this study has contributed to the available knowledge. The diversity of arbuscular mycorrhizal fungi naturally present in the soils of coffee can be selected and used in reforestation and restoration of degraded ecosystems and even in improving the production of vigorous coffee plants.

fungi and drought stress. Mycorrhiza, 14: 263269.

Bellgard S.E., Whelan R.J. and R.M. Muston R.M., 1994. The impact of wildfire on vesiculararbuscular mycorrhizal fungi and their potential to influence there establishment of post-fire communities. Mycorrhiza, 4: 139-146.

Bethlenfalvay G.J. and Lindcnnan R.G., 1992. Mycorrhizae in Sustainable Agriculture, Am. 
Soc. Agron. Special Publication 54, American .Society of Agronomy, Madison.

Bever J.D., 2002. Host-specificity of AM fungal population growth rates can generate feedback on plant growth. Plant Soil, 244 (12): 281 - 290.

Bever J.D., Morton J.B., Antonovics J. and Schultz P.A., 1996. Host dependent sporulation and species diversity of arbuscular mycorrhizal fungi in a mown grassland. J. Ecol., 84:71-82.

Bolan N.S., 1991. A critical review of the role of mycorrhizal fungi in the uptake of phosphorus by plants. Plant Soil, 134: 189-208.

Bolan N.S., Robson A.D. and Barrow N.J., 1987. Effects of vesicular-arbuscular mycorrhizae on the availability of iron phosphates to plants. Plant Soil, 99: 401-410.

Branzanti B., Gianinazzi-Pearson V., Gianinazzi S., 1992. Influence of phosphate fertilization on the growth and nutrient status of micropropagated apple infected with endomycorrhizal fungi during the weaning stag, Agronomie, 12(10): 841-845.

Brundrett M.C., Abbott L.K and Jasper D. A., 1999. Glomalean mycorrhizal fungi from tropical Australia. I. Comparison of effectiveness and specificity of different isolation procedures. Mycorrhiza, 8: 305-314.

Caravaca F., Barea J.M., Palenzuela J., Figueroa D., Alguacil M.M. and Roldán A., 2003. Establishment of shrub species in a degraded semiarid site after inoculation with native or allochthonous arbuscular mycorrhizal fungi. Appl. Soil Ecol., 22(2): 103- 111.

Charrier A., Berthaud J., 1985. Botanical classification of coffee. In: Clifford M.N., Wilson K.C. (eds.) Coffee: botany, biochemistry and production of beans and beverage. Croom Helm Ltd Publishers, Beckentham, UK, pp 13-47.

Chevalier A., Dagron M., 1928. Recherches historiques sur les débuts de la culture du caféier en Amérique. Communications et Actes de l'Académie des Sciences Coloniales, Paris.

Cruz S.J.C., 1989. Estudio de la simbiosis micorrizica vesicular arbuscular en el cultivo de Coffea arabica var. caturra. Fitopatol Colomb., 13:5664.

Dalpé Y., 1989. Inventaire et répartition de la flore endomycorhizienne de dunes et de rivages maritimes du Québec, du Nouveau -
Brunswick et de la nouvelle. Ecosse. Rev. Ecol. Syst., 116: $219-236$.

Daniels B.A., and Skipper H.D., 1982. Methods for the Recovery and quantitative estimation of propagules from soil. In: N.C. Schenck, (ed.), Methods and Principles of Mycorrhizal Research. American Phytopathological Society, St Paul, Minnesota, pp: 29-37.

Derkowska E., Sas-Paszt L., Sumorok B., Szwonek E. \& Gluszek S., 2008. The influence of mycorrhization and organic mulches on mycorrhizal frequency in apple and strawberry roots. Journal of Fruit and Ornamental Plant Research, 16 : 227-242.

Duponnois R., Colombet A., Hien V., Thioulouse J., 2005. The mycorrhizal fungus Glomus intraradices and rock phosphate amendment influence plant growth and microbial activity in the rhizosphere of Acacia holosericea. Soil Biol. Biochem., 37: 1460-1468.

Estrada-Luna A.A., Davies Jr. F.T., 2003. Arbuscular mycorrhizal fungi influence water relations, gas exchange, abscisic acid and growth of micropropagated chile ancho pepper (Capsicum annum) plantlets during acclimatization and postacclimatization. Journal of Plant Physiology, 160: 1073-1083.

FAO, 2006. Country Pasture/Forage Resource Profiles YEMEN, $19 \mathrm{pp}$.

Fernández-Martín F., Rivera-Espinosa R.A., Hernández-Jiménez A., Herrera-Peraza R. A. and Fernández-Suárez K., 2005. Inoculation of arbuscular mycorrhizal fungi and different soil: Earthworm humus ratios on coffee growth (Coffea arabica L.) cv. Catuaí at the nursery stage. Revista Chapingo- Serie Horticultura, 11: $175-184$.

Frioni L., Minasian H. and Volfovicz R., 1999. Arbuscular mycorrhizae and ectomycorrhizae in native tree legumes in Uruguay. For. Ecol. Manag., 115: 41-47.

Furlan V., Bartschii H. and Fortin J. A., 1980. Media for density gradient extraction of endomycorrhizal spores. Trans. Br. Mycol. Soc., 75: 336-338.

Geissert K. D.and Ebañez A., 2008. Calidad y ambiente fisico de los suelos. In: Manson R.H, Hernández-Ortiz V., Gallina S., Mehltreter K. (Eds.) Agroecosistemas cafetaleros de Veracruz. Biodiversidad, manejo yconservación. Instituto de Ecologia.Instituto 
Nacional de Ecologia Mexico DF, pp. 213221.

Gemma J.N., Koske R.E. and Carreiro M., 1989. Seasonal variation in spore abundance and dormancy of Gigaspora gigantea in Mycorrhizal inoculum potential of a dune soil. Mycologia, 80: 211-216.

George E., Haussler K., Vetterlein D., Gorgus E. and Marschner H., 1992. Water and nutrient translocation by hyphae of Glomus mosseae. Can. J. Bot., 70: 2130-2137.

Gerdemann J. W. and Nicolson T. H., 1963. Spores of mycorrhizal Endogone sp. extracted from soil by wet sieving and decanting. Trans. Brit. Mycol. Soc., 46: 235-244.

Gianinazzi-Pearson V., 1982. Importance des mycorhizes dans la nutrition et la physiologie des plantes. In: Les mycorhizes, partie intégrante de la plante: biologie et perspectives d'utilisation. Les colloques de I'INRA $n^{\circ} 13$, Gianinazzi S., GianinazziPearson V., Trouvelot A. (eds), INRA, Paris, 51-59.

Giovanneti M. and Mosse B., 1980. An evaluation of techniques for measuring vesicular-arbuscular mycorrhizal infection in roots. New Phytol., 84(3): 489- 500.

Guadarrama P. and Alvarez-Sanches F.J., 1999. Abundance of arbuscular mycorrhizal fungi spores in different environments in a tropical rain forest, Veracruz, Mexico. Mycorrhiza, 8: 267-270.

Habte M. and Bittenbender H. C., 1999. Reactions of coffee to soil solution $P$ concentration and arbuscular mycorrhizal colonization. Journal of South Pacific Agriculture, 6: 29-34.

Hayman D.S., 1983. The physiology of vesiculararbuscular endomycorrhizal symbiosis. Can. J. Bot., 61, 944-963

Hebert R. D., Outlaw W.H., Aghoram K., Lumsden A.S., Riddle K.A., and Hampp R., 1999. Visualization of mycorrhizal fungi. Pages 353355, In: Tested studies for laboratory teaching, Volume 20 (Karcher S.J., Editor). Proceedings of the $20^{\text {th }}$ Workshop/Conference of the Association for Biology Laboratory Education (ABLE), $399 \mathrm{p}$.

Jamil Mohammad M., S. Rushdi Hamadt S., and Issa Malkawit H., 2003. Population of arbuscular mycorrhizal fungi in semi-arid environment of Jordan as influenced by biotic and abiotic factors. Journal of Arid Environments, 53: 409417.

Janse J.M., 1897. Les endophytes radicaux de quelques plantes javanaises. Annales du Jardin Botanique de Buitenzorg, 14: 53-201.

Jeffries P., Gianinazzi S., Perotto S., Turnau K. and Barea J.M., 2003. The contribution of arbuscular mycorrhizal fungi in sustainable maintenance of plant health and soil fertility. Biol. Fertil. Soils, 37: 1-16.

Jefwa J.M., Mung'atu J., Okoth P., Muya E., Roimen H. and Njuguini S., 2009. Influence of Land use types on occurrence of arbuscular mycorrhizal fungi in the high altitude regions of Mt. Kenya. Trop. Subtrop. Agroecosystems, 11: 277-290.

Johnson N.C., Zak D.R., Tilman D. and Pfleger F.L., 1991. Dynamics of vesicular-arbuscular mycorrhizae during old-field succession. Oecologia, 86: 349-358.

Koske R. E., 1987. Distribution of VA mycorrhizal fungi along a latitudinal temperature gradient. Mycologia, 79: 55-68.

Krug C.A., Mendes J.E.T. and Carvalho A., 1938. Taxonomia de Coffea arabica L. Descrição das variedades e formas encontradas no Estado de São Paulo. Boletim Técnico do Instituto Agronômico. Campinas, Brasil, 62:157.

Lewin B., Giovannucci D., and Varangis P., 2004. Coffee Markets: New Paradigms in global supply and demand. The International Bank for Reconstruction and Development, Agriculture and Rural Development Discussion Paper 3.

Lopes E.S., Oliveira E., De Dias R.A. and Schenck N.C., 1983. Occurrence and distribution of vesicular arbuscular mycorrhizal fungi in coffee (Coffea arabica L.) plantations in central Sao Paulo State, Brazil. Turrialba, 33: 417-422.

Mangan Scott A. and Adler Gregory H., 2000. Consumption of arbuscular mycorrhizal fungi by terrestrial and arboreal small mammals in a Panamanian cloud forest. Journal of Mammalogy, 81(2): 563-570.

Marschner H., 1995. Function of mineral nutrients: Micronutrients. In: Mineral nutrition of higher plants. 2nd ed. Academic Press, London, UK: 347-364.

Miller R.M., and Jastrow J.D., 1994. Vesiculararbuscular mycorrhizae and bíogeochemical cycling. In: F.L. pfleger and R.G. Undennan 
(eds.) Mycorrhizae and Plañi Health, APS Press, St. Paul, pp. 189-212.

Muleta D., Assefa F., Nemomissa S. and Granhall U., 2008. Distribution of arbuscular mycorrhizal fungi spores in soils of smallholder agroforestry and monocultural coffee systems in southwestern Ethiopia. Biol Fertil. Soils, 44: 653-659.

Mutandwa E., Kanuma N.T., Rusatira E., Kwiringirimana T., Mugenzi P., Govere I. and Foti R., 2009. Analysis of coffee export marketing in Rwanda: Application of the Boston consulting group matrix. African Journal of Business Management, 2(4): 210219.

O'Neill R.V. and Waíde J.B., 1991. Hicrarchy theory as a guide to mycorrhizal research on large-scale problems. Enviwn. Pollu., 73: 271-284.

Osorio N., 2002. The global coffee crisis: A threat to sustainable development. International Coffee Organization, London, $4 p$.

Phillips J.M. and Hayman D.S., 1970. Improved procedures for clearing roots and staining parasitic and vesicular arbuscular mycorrhizal fungi for rapid assessment of infection. Trans. Br. Mycol. Soc., 55: 158-161.

Rai, M. K., 2001. Current advances in mycorrhization in micropropagation. In Vitro Cell. Dev. Biol. /Plant, 37:158-167

Redhead J.F., 1975. Endotrophic mycorrhizas in Nigeria: some aspects of the ecology of the endotrophic mycorrhizal association of Khaya grandifoliola C.DC. In: Sanders F. E., Mosse B., Tinker P.B. (eds.) Endomycorrhizas. Academic, London, pp. 447-459.

Rosendahl C.N. and Rosendahl S., 1991. Influence of vesicular arbuscular mycorrhizal fungi (Glomus spp.) on the response of cucumber (Cucumis sativus L.) to salt stress. Environ. Exp. Bot., 31: 313-318.

Selosse M.A., Baudoin E. and Vandenkoornhuyse P., 2004. Symbiotic microorganisms, a key for ecological success and protection of plants. $C$. R. Biol., 327: 639-648.

Sghir F., Chliyeh M., Kachkouch W., Khouader M., Ouazzani Touhami A., Benkirane R. and Douira A., 2013. Mycorrhizal status of Olea europaea spp. oleaster in Morocco. Journal of Applied Biosciences, 61: 4478 - 4489.
Sieverding E., 1991. Vesicular-arbuscular Mycorrhiza Management in Tropical Agrosystems. GTZ, Eschborn, Germany, 371p.

Sieverding E. and Toro S. T., 1986. The genus Entrophospora in Colombia. In Physiological and Genetical Aspects of Mycorrhizae (Eds V. Gianinazzi- Pearson \& S. Gianinazzi), pp. 621-626. Paris, France: INRA.

Siqueira J. O., Colozzi-filho A., Saggin-junior O. J., Guimarães P. T.G., and Oliveira E., 1993. Crescimento de mudas e produção do cafeeiro sob influênciade fungos micorrízicos e superfosfato. Revista Brasileira de Ciênciado Solo, 17 (1):53-60.

Siqueira J. O., Saggin-junior O. J., Flores-aylas W. W. and Guimarães P. T. G., 1998. Arbuscular mycorrhizal inoculation and superphosphate application influence plant development and yield of coffee in Brazil. Mycorrhiza, 7: 293300.

Smith S.E. and Read D.J., 1997. Mycorrhizal Symbiosis. Academic Press, San Diego, p. 607.

Smith T.F., 1980. The effect of season and crop relation with abundance of spores of vesicular Arbuscular (VA) mycorrhizal endophytes. Plant and soil, 57: 475-479.

St. John T. V., 1980. A survey of mycorrhizal infection in an Amazonian rain forest. Acta Amazonica, 10: 527-533.

Stutz J. C. and Morton J. B., 1996. Successive pot cultures reveal high species richness of arbuscular endomycorrhizal fungi in arid ecosystems. Can. J. Bot., 74: 1883-1889.

Tadesse C., 2006. Arbuscular Mycorrhizal Fungal diversity of Coffee and Shade trees of Bonga forest, South Western Ethiopia. A Thesis Submitted to the school of graduate studies Department of Biology In partial fulfillment of the requirements of the degree of Master's of science in Biology, Applied Microbiology, pp. $1-47$.

Trappe J., 1987. Phylogenetic and ecologic aspects of mycotrophy in the angiosperms from an evolutionary standpoint In: Safir G.R., ed. Ecophysiology of VA mycorrhizal plants. Boca Raton, Florida, USA: CRC Press, pp. 5-25.

Utobo E.B, Ogbodo E.N. and Nwogbaga A.C., 2011. Techniques for extraction and quantification of arbuscular mycorrhizal fungi. Libyan 
Agriculture Research Center Journal International, 2 (2): 68-78.

Virant I. and Lucka Kaitez-Boqata L., 1988. Vesiculararbuscular mycorrhiza in buckwheat. Fagopyrum, 8: 10-14.

Mahesh V. and Selvaraj T., 2008. Occurrence and distribution VA-Mycorrhizal Fungi in the soils polluted with Tannery Effluent. Advanced Biotech., pp. 34-36

Twum-Ampofo K., 2008. Growth response of Gliricidia sepium (Jacq.) Walp. to inoculation with different arbuscular mycorrhizal (AM) fungi. J. Sci. Technol., 28:56-66.

Schenck N.C. and Perez Y., 1990. Isolation and culture of VA mycorrhizal fungi, In: D.P. Labeda, (ed.), Isolation of Biotechnological organisms from Nature. McGraw-Hill Book Co., New York, pp: 237-258.
Webet T., Weiß M., Kottle I., Teketay D. and Oberwinkler F., 2004. Molecular diversity of arbuscular mycorrhizal fungi in Prunus africana, an endangered medicinal tree species in dry Afromontane forests of Ethiopia, New Phytologist, 161 (2): 517- 528.

Wilson J.M. and Tommerup I.C., 1992. Interactions between fungal symbionts: VA mycorrhizae. In: Mycorrhizal functioning: An integrative plant-fungal process. Allen MF (ed.). pp 199248, Chapman and Hall, New York.

Zhao Z.W., Xia Y.M., Qin X.Z., Li X.W., Cheng L.Z., Sha T. and Wang, G.H., 2001. Arbuscular mycorrhizal status of plants and the spore density of arbuscular mycorrhizal fungi in the tropical rain forest of Xishuangbanna, southwest China. Mycorrhiza, 11: 159-162. 